\title{
The Iceland Deep Drilling Project 4.5 km deep well, IDDP-2, in the seawater-recharged Reykjanes geothermal field in SW Iceland has successfully reached its supercritical target
}

\author{
Guðmundur Ó. Friðleifsson ${ }^{1}$, Wilfred A. Elders ${ }^{2}$, Robert A. Zierenberg ${ }^{3}$, Ari Stefánsson ${ }^{1}$, \\ Andrew P. G. Fowler ${ }^{3}$, Tobias B. Weisenberger ${ }^{4}$, Björn S. Harðarson ${ }^{4}$, and Kiflom G. Mesfin ${ }^{1}$ \\ ${ }^{1}$ HS Orka, Svartsengi, 240 Grindavík, Iceland \\ ${ }^{2}$ Department of Earth Sciences, University of California, Riverside, CA 92521, USA \\ ${ }^{3}$ Department of Earth and Planetary Sciences, University of California, Davis, CA 95616, USA \\ ${ }^{4}$ ÍSOR, Grensásvegur 9, 108 Reykjavík, Iceland \\ Correspondence to: Guðmundur Ó. Friðleifsson (gof@hsorka.is)
}

Received: 15 June 2017 - Revised: 25 August 2017 - Accepted: 4 September 2017 - Published: 30 November 2017

\begin{abstract}
The Iceland Deep Drilling Project research well RN-15/IDDP-2 at Reykjanes, Iceland, reached its target of supercritical conditions at a depth of $4.5 \mathrm{~km}$ in January 2017. After only 6 days of heating, the measured bottom hole temperature was $426^{\circ} \mathrm{C}$, and the fluid pressure was $34 \mathrm{MPa}$. The southern tip of the Reykjanes peninsula is the landward extension of the Mid-Atlantic Ridge in Iceland. Reykjanes is unique among Icelandic geothermal systems in that it is recharged by seawater, which has a critical point of $406^{\circ} \mathrm{C}$ at $29.8 \mathrm{MPa}$. The geologic setting and fluid characteristics at Reykjanes provide a geochemical analog that allows us to investigate the roots of a mid-ocean ridge submarine black smoker hydrothermal system.

Drilling began with deepening an existing $2.5 \mathrm{~km}$ deep vertical production well (RN-15) to $3 \mathrm{~km}$ depth, followed by inclined drilling directed towards the main upflow zone of the system, for a total slant depth of $4659 \mathrm{~m}$ ( $\sim 4.5 \mathrm{~km}$ vertical depth). Total circulation losses of drilling fluid were encountered below $2.5 \mathrm{~km}$, which could not be cured using lost circulation blocking materials or multiple cement jobs. Accordingly, drilling continued to the total depth without return of drill cuttings. Thirteen spot coring attempts were made below $3 \mathrm{~km}$ depth. Rocks in the cores are basalts and dolerites with alteration ranging from upper greenschist facies to amphibolite facies, suggesting that formation temperatures at depth exceed $450^{\circ} \mathrm{C}$.

High-permeability circulation-fluid loss zones (feed points or feed zones) were detected at multiple depth levels below $3 \mathrm{~km}$ depth to bottom. The largest circulation losses (most permeable zones) occurred between the bottom of the casing and $3.4 \mathrm{~km}$ depth. Permeable zones encountered below $3.4 \mathrm{~km}$ accepted less than $5 \%$ of the injected water. Currently, the project is attempting soft stimulation to increase deep permeability. While it is too early to speculate on the energy potential of this well and its economics, the IDDP-2 is a milestone in the development of geothermal resources and the study of hydrothermal systems. It is the first well that successfully encountered supercritical hydrothermal conditions, with potential high-power output, and in which on-going hydrothermal metamorphism at amphibolite facies conditions can be observed. The next step will be to carry out flow testing and fluid sampling to determine the chemical and thermodynamic properties of the formation fluids.
\end{abstract}




\section{Introduction}

The Iceland Deep Drilling Project (IDDP) is a long-term project (https://www.iddp.is) aimed at greatly increasing the production of usable geothermal energy by drilling deep enough to reach the supercritical conditions believed to exist beneath high-temperature geothermal fields in Iceland. When the IDDP consortium was formed in the year 2000, three geothermal fields in Iceland were chosen as suitable locations to search for supercritical resources, Krafla in the northeast of Iceland, and Hengill and Reykjanes in the southwest (Friðleifsson et al., 2003; see Fig. 1). The first attempt to drill into a supercritical reservoir was made in 2008-2009 in the Krafla caldera (IDDP-1), but the well did not attain supercritical fluid pressures because drilling was suspended at too shallow of a depth (Elders et al., 2011). This was because drilling intercepted $900^{\circ} \mathrm{C}$ rhyolite magma at a depth of only $2100 \mathrm{~m}$. However, the IDDP-1 was completed with a liner set above the rhyolite intrusion. When the well was tested, it produced superheated $452^{\circ} \mathrm{C}$ steam at 140 bar pressure, and had a flow rate and pressure sufficient to generate about $35 \mathrm{MWe}$. After 2 years of flow testing, repair of the surface installations was necessary, and the well had to be quenched due to failure of the master valves. Unfortunately, this caused a collapse of the well casing and the well was abandoned.

In 2013, as reported previously in this journal (Friðleifsson et al., 2013), the IDDP began planning to drill a deep exploratory/research well, the IDDP-2, in the Reykjanes geothermal field in SW Iceland, where HS Orka generates up to $100 \mathrm{MWe}$ of electric power. From a scientific perspective, this location is of great interest because the Reykjanes peninsula is the landward extension of the Mid-Atlantic Ridge (Fig. 1).

The exposed rocks in Iceland date back to about $16 \mathrm{Ma}$, the oldest rocks being exposed farthest to the west and farthest to the east, and include about 100 central volcanic complexes of different ages. In Fig. 1 we only show the active central volcanoes associated with on-going rifting at a slow spreading rate of $1.8 \mathrm{~cm} \mathrm{yr}^{-1}$. The active rift systems typically show an evolution characterized by development of central volcanoes near the spreading segment centers. Central volcanoes often mature to develop rhyolitic volcanism and calderas over time frames of about $1 \mathrm{My}$ before drifting out of the active spreading zone and cooling down. Many of the high-temperature geothermal areas in Iceland are associated with central volcanoes, for example the Krafla volcano, which displays extensive rhyolitic volcanism and caldera collapse (e.g., Fridleifsson et al., 2003), and which was the site of the IDDP-1 drill hole. The Reykjanes system is in an early rifting stage and has not developed into a central volcano, while the Hengill central volcano, the proposed site for IDDP-3 drilling, is considered to be in an intermediate stage of development as it has not generated large volumes of felsic rock and has yet to develop a caldera.

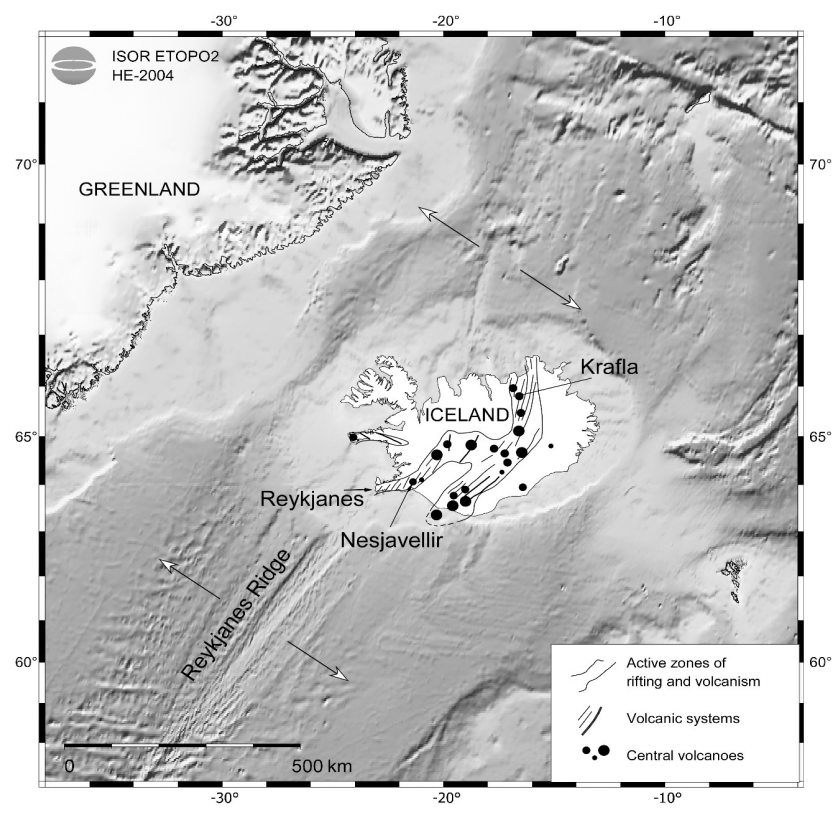

Figure 1. The location of Iceland on the Mid-Atlantic Ridge. The arrows show the spreading directions on the Reykjanes ridge to the south and the Kolbeinsey Ridge to the north. Iceland's neovolcanic zone with its active central volcanoes and the location of the three high-temperature hydrothermal systems of Reykjanes, Nesjavellir (in the Hengill volcano), and Krafla, targeted for IDDP deep drilling, are also shown.

The drilling target for each of the IDDP sites is to reach supercritical conditions. The critical point of fresh water, which characterize the Krafla and Hengill fields, occurs at $374^{\circ} \mathrm{C}$ and $22.1 \mathrm{MPa}$. The reservoir fluids currently produced from the Reykjanes field have a salinity of seawater, which has a critical point of $406^{\circ} \mathrm{C}$ at $29.8 \mathrm{MPa}$ (Bischoff and Rosenbauer, 1988). As described below, it is already clear that conditions at the bottom of the IDDP-2 well measured during drilling exceed the critical point of seawater. A geothermal well producing from a supercritical geothermal reservoir has the potential to generate power outputs on an order of magnitude greater than conventional high-temperature wells (at $240-340^{\circ} \mathrm{C}$ ) assuming the same volumetric flow rate of steam (Albertsson et al., 2003; Friðleifsson et al., 2014a).

The Reykjanes hydrothermal resource is a two-phase geothermal system to about $1500 \mathrm{~m}$ depth, where temperature follows the boiling point curve with increasing depth and both liquid and vapor are present, below which the temperatures are approximately constant to about $3 \mathrm{~km}$ depth, with the highest recorded downhole temperature of about $320^{\circ} \mathrm{C}$ (Friðleifsson et al., 2014b). The depth to the bottom of the hydrothermal reservoir is not known, while $3 \mathrm{~km}$ depth has been used in reservoir modeling so far for the convection system. The primary motivation for the Reykjanes field operator to undertake such a challenging drilling operation as IDDP-2 


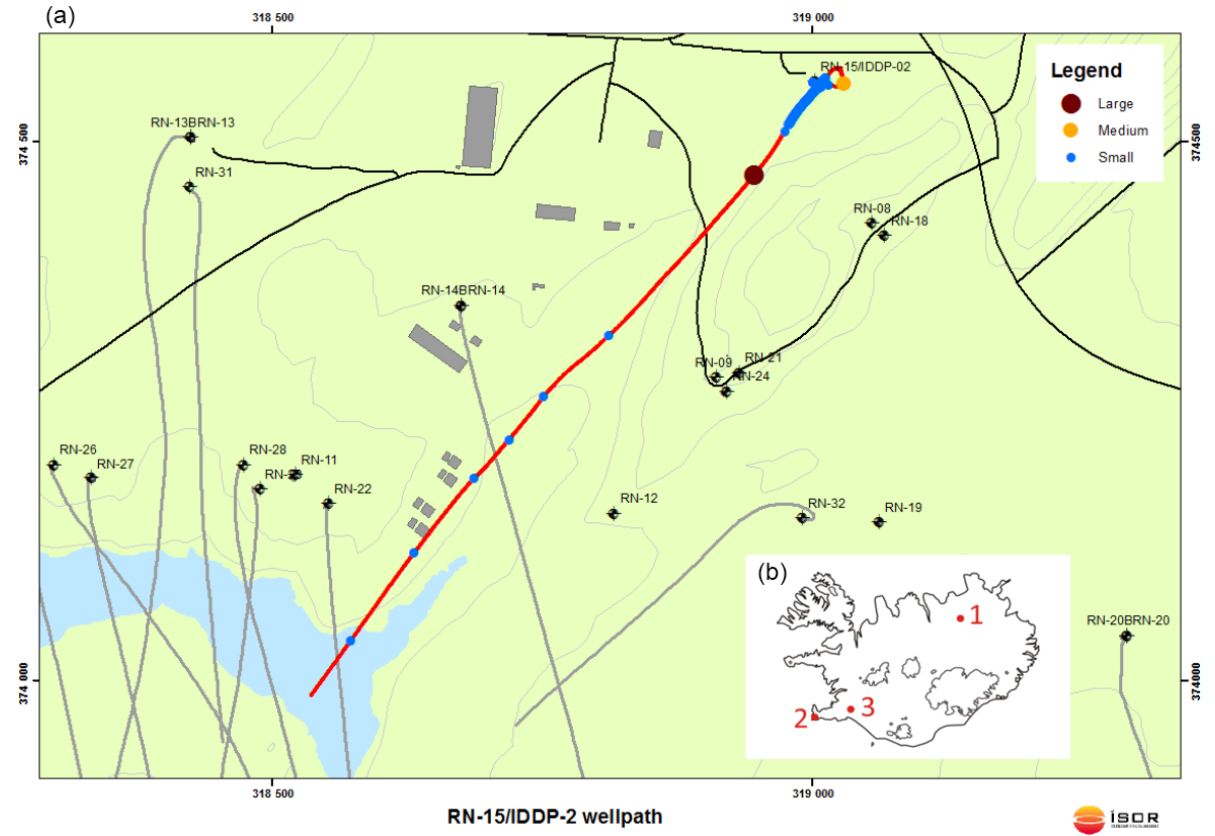

Figure 2. The locations and tracks of wells in the Reykjanes geothermal field (Weisenberger et al., 2017). The red line shows the track of well RN-15/IDDP-2. The relative size of the circulation loss zones are shown with circles (see legend). The inset (bottom right) shows the location of the geothermal fields at Krafla (1), Reykjanes (2), and Hengill (3).

was to address several basic questions important for the future development of the geothermal resource:

i. What is the nature and location of the base of the Reykjanes hydrothermal reservoir? Is it possibly heated by superheated steam from below?

ii. Can deeper heat sources be exploited by injecting fluid into the hot rocks beneath the current production zone?

iii. Will productive permeability be found at these great depths within the approximate center of the fault-related upflow zone?

iv. Does a hydrothermal reservoir at supercritical condition exist at 4-5 km depth under the Reykjanes well field or does it lie even deeper? Alternatively, will we be dealing with hot dry rocks at those depths?

v. What is the ultimate heat source of this saline oceanfloor-related hydrothermal system?

In December 2015, the plans for the IDDP-2 were accepted as a part of the European Union Horizon 2020 program DEEPEGS (Deployment of Deep Enhanced Geothermal Systems for Sustainable Energy Business, grant no. 690771). DEEPEGS is a major effort to speed up the development of enhanced geothermal systems within Europe and worldwide, for both high- and low-enthalpy systems.

A drill site was selected on the north side of the Reykjanes drill field (Fig. 2) making use of an existing production well RN-15 as a "well of opportunity". In 2004, RN-15 was drilled vertically to a depth of $2500 \mathrm{~m}$ with a production casing cemented down to $794 \mathrm{~m}$, and open hole below. The well was suitably sited within the Reykjanes geothermal system for a deepening as an inclined IDDP well, and the potential risk for affecting other production wells during the drilling and cementing operations to $3 \mathrm{~km}$ depth was relatively small. Therefore, after serious consideration of the economics as well, IDDP was offered the opportunity to deepen well RN15. The well is now identified as RN-15/IDDP-2. The RN15 was cooled down slowly, deepened with a $12 \frac{1}{4}^{\prime \prime}$ bit to $3000 \mathrm{~m}$, and a new production casing was cemented in place. Drilling then continued with $8 \frac{1}{2}$ " rotary bits towards a target depth of $5 \mathrm{~km}$. We planned to drill $8 \frac{1}{2}{ }^{\prime \prime}$ spot cores over about $10 \%$ of the total drilling interval.

The RN-15/IDDP-2 passed a significant milestone in geothermal research by reaching a slant depth of $4659 \mathrm{~m}$ on 25 January 2017, after 168 days of drilling. Drilling achieved its initial targets to: (a) drill deep enough to reach supercritical conditions (4 to $5 \mathrm{~km}$ ), (b) measure the fluid temperature and pressure, (c) search for permeable zones, and (d) recover drill cores.

\section{The Reykjanes drill field}

Prior to the IDDP-2, the deepest producing geothermal wells existing at Reykjanes were about $2.5 \mathrm{~km}$ deep. Figure 2 is a map showing the deviated track of well RN-15/IDDP-2, as it was drilled, together with the tracks of existing wells. Ver- 

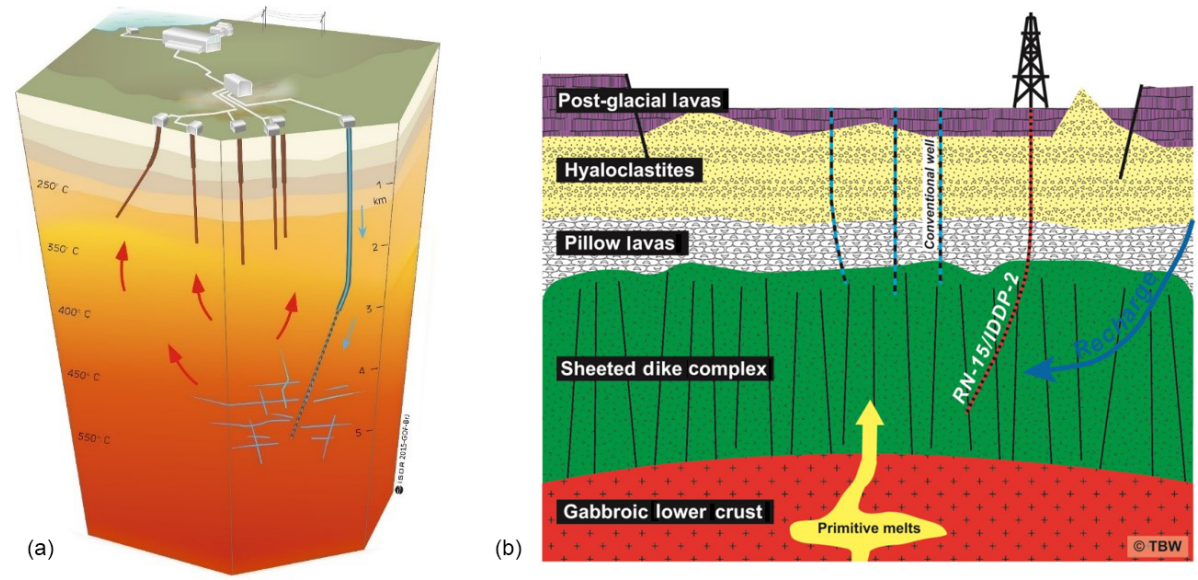

Figure 3. (a) Conceptual model of the roots of the Reykjanes Geothermal field indicating existing wells (brown) and the planned track of the IDDP-2 well (blue) to intersect the supercritical zone beneath the producing reservoir. (b) Schematic lithological model of the crust beneath the Reykjanes peninsula, which, below a thin apron of subaerial lava flows of Holocene age, is mostly composed of subglacial and marine tuffs, shallow marine sediments, and pillow basalts down to $2-3 \mathrm{~km}$ depth, increasingly intruded by dikes with increasing depth. This culminates in a sheeted dike complex which extends for several kilometers, presumably underlain by a gabbroic lower crust.

tical wells are represented by dots only. Figure $3 \mathrm{a}$ is a simplified conceptual model of the Reykjanes drill field, showing the well RN-15/IDDP-2 directionally drilled towards $5 \mathrm{~km}$ depth and ending under the main drill field at temperatures anticipated to range from $400-500{ }^{\circ} \mathrm{C}$. Figure $3 \mathrm{~b}$ is a schematic lithological diagram (Weisenberger et al., 2017), based on lithological logs from about 34 drill holes. Below a pile of several Holocene subaerial lava flows, the rock formations are composed of shallow marine sediments and tuffs, with intervals of pillow basalt and breccia, emplaced in the last $\sim 0.5 \mathrm{Ma}$ (Friðleifsson and Richter, 2010). The dike intensity increases dramatically with increasing depth and reaches $\sim 100 \%$ below approximately $3 \mathrm{~km}$ depth. This sheeted dike complex is presumably underlain by gabbroic lower crust, a model that conforms to typical "classical" ophiolite (Anonymous, 1971). Although the Reykjanes ridge is a slow spreading ridge, it is magmatically robust due to the influence of the Iceland hotspot. Enhanced magmatism results in much thicker crust $(\sim 16 \mathrm{~km})$ compared to normal mid-ocean ridges (Weir et al., 2001). While the ophiolite conceptual model (Fig. 3b) has been assumed for the Reykjanes field, the RN-15/IDDP-2 well is the first to confirm the presence of a thick sheeted dike section (see below). The nature of the lower crust and the depth to any large gabbroic intrusions is unknown.

\section{Drilling the RN-15/IDDP-2}

The Iceland Drilling Company (IDC) began deepening well RN-15 on 11 August 2016, using the rig Thor (Pór), a Bentec 350-ton drilling rig with an electric top drive (MH PTD500-AC). On 8 September after 29 working days, drilling to $3000 \mathrm{~m}$ depth was completed (Table 1). Well RN-15 had an existing $13 \frac{3}{8}$ " production casing cemented from 0 to $793.8 \mathrm{~m}$. An additional production casing (anchor casing) of $9 \frac{7^{\prime \prime}}{8}$ (from surface to $445 \mathrm{~m}$ ) and $9 \frac{5^{\prime \prime}}{8}(2932.4 \mathrm{~m}$ ) was run into the hole and cemented (see Table 1) (Weisenberger et al., 2016).

The RN-15/IDDP-2 was drilled vertically from $2500 \mathrm{~m}$ down to $2750 \mathrm{~m}$, and below that drilled directionally to the southwest to intersect the main upflow zone of the Reykjanes system. The bottom of the well is at a vertical depth of about $4500 \mathrm{~m}$, and is situated $738 \mathrm{~m}$ southwest of the wellhead.

Cables with eight thermocouples from Petrospec Engineering were attached to the outside of the casing string as it was run into the hole. The thermocouples were rated to tolerate up to $600^{\circ} \mathrm{C}$. They were expected to enable continuous measurement of temperatures at $341,641,941,1541,1841$, 2141,2341 , and $2641 \mathrm{~m}$ depths. The thermocouple at $2141 \mathrm{~m}$ was damaged during insertion of the casing. In addition, a pressure/temperature sensor was installed at $1241 \mathrm{~m}$ depth, and a fiber optic cable for temperature, strain, and seismic measurements was installed by GFZ Potsdam (Geoforschung Zentrum) to $841 \mathrm{~m}$ depth, supported by two EU funded programs (IMAGE and GEOWELL) together with DEEPEGS, HS Orka, and Statoil. Data from these sensors were used to evaluate the progress of the cementing operation.

Reverse cementing, with $\sim 150 \mathrm{~m}^{3}$ of cement pumped down the annulus between the casing and the borehole, was completed on 6 September, followed by two separate downhole cement bond logging trips inside the casing, which indicated that a proper cementing job had been achieved. The result is the longest production casing ever installed in any Icelandic high-temperature geothermal field.

Drilling in formations below $3000 \mathrm{~m}$ in the production part of the well began on 17 September (the 38th workday), and 
Table 1. Drilling and casing depths in well RN-15 and RN-15/IDDP-2.

\begin{tabular}{|c|c|c|c|c|c|c|c|c|}
\hline ID & Drill rig & Phase & $\begin{array}{l}\text { Depth } \\
(\mathrm{m})\end{array}$ & $\begin{array}{l}\text { Depth } \\
\text { reference }\end{array}$ & $\begin{array}{l}\text { Bit } \\
\text { size }\end{array}$ & $\begin{array}{l}\text { Casing } \\
\text { type }\end{array}$ & $\begin{array}{l}\text { Casing } \\
\text { depth }(m)\end{array}$ & $\begin{array}{l}\text { Casing-depth } \\
\text { reference }\end{array}$ \\
\hline $\mathrm{RN}-15$ & Saga & Pre-drilling & 86.5 & Saga RF & $26^{\prime \prime}$ & $22 \frac{1}{2}^{\prime \prime}$ & 84.4 & Ground surface \\
\hline $\mathrm{RN}-15$ & Jötunn & 1. phase & 300 & Jötunn RF & $21^{\prime \prime}$ & $18 \frac{5}{8}^{\prime \prime}$ & 292.8 & Ground surface \\
\hline $\mathrm{RN}-15$ & Jötunn & 2. phase & 804 & Jötunn RF & $17 \frac{1}{2}^{\prime \prime}$ & $13 \frac{3}{8}$ & 793.8 & Ground surface \\
\hline $\mathrm{RN}-15$ & Jötunn & 3. phase & 2507 & Jötunn RF & $12 \frac{1}{4}^{\prime \prime}$ & & & \\
\hline \multirow[t]{2}{*}{ RN-15/IDDP-2 } & Thor & 3. phase & 3000 & Thor RF & $12 \frac{1}{4}^{\prime \prime}$ & $9 \frac{7}{8}^{\prime \prime}$ & $0-445$ & Ground surface \\
\hline & & & & & & $9 \frac{5}{8}^{\prime \prime}$ & $445-2932.4$ & Ground surface \\
\hline
\end{tabular}

Table 2. Overview of the 13 core runs attempted in well RN-15/IDDP-2 at Reykjanes. ROP is rate of penetrations.

\begin{tabular}{llrrrrr}
\hline Core run & Start & $\begin{array}{r}\text { Coring interval } \\
(\mathrm{m})\end{array}$ & $\begin{array}{r}\text { Cored } \\
\text { length } \\
(\mathrm{m})\end{array}$ & $\begin{array}{r}\text { Drilling } \\
\text { time } \\
(\mathrm{h})\end{array}$ & $\begin{array}{r}\text { ROP } \\
\left(\mathrm{m} \mathrm{h}^{-1}\right)\end{array}$ & $\begin{array}{r}\text { Core } \\
\text { recovered } \\
(\mathrm{m})\end{array}$ \\
\hline 1 & $18 / 09 / 2016$ & $3068.7-3074.1$ & 5.4 & 7.12 & 0.8 & \\
2 & $04 / 10 / 2016$ & $3177.6-3179.0$ & 1.4 & 2 & 0.7 & \\
3 & $30 / 10 / 2016$ & $3648.0-3648.9$ & 0.9 & 5 & 0.2 & 0.52 \\
4 & $02 / 11 / 2016$ & $3648.9-3650.7$ & 1.8 & 10.25 & 0.2 & \\
5 & $11 / 11 / 2016$ & $3865.5-3869.8$ & 4.3 & 8.5 & 0.6 & 3.85 \\
6 & $12 / 11 / 2016$ & $3869.8-3870.2$ & 0.4 & 2.5 & 0.2 & 0.15 \\
7 & $22 / 11 / 2016$ & $4089.5-4090.6$ & 1.1 & 2.25 & 0.5 & 0.13 \\
8 & $28 / 11 / 2016$ & $4254.6-4255.3$ & 0.7 & 5.5 & 0.1 & 0.28 \\
9 & $06 / 12 / 2016$ & $4308.7-4309.9$ & 1.2 & 3 & 0.4 & \\
10 & $07 / 12 / 2016$ & $4309.9-4311.2$ & 1.3 & 8.25 & 0.2 & 0.22 \\
11 & $16 / 01 / 2017$ & $4634.2-4642.8$ & 8.6 & 1.25 & 6.9 & 7.58 \\
12 & $17 / 01 / 2017$ & $4642.8-4652.0$ & 9.2 & 1 & 9.2 & 9 \\
13 & $19 / 01 / 2017$ & $4652.0-4659.0$ & 7 & 0.75 & 9.3 & 5.58 \\
\hline Total & & & 43.3 & & & 27.31 \\
\hline
\end{tabular}

was concluded on 26 January 2017 (the 168th workday) at $4659 \mathrm{~m}$ (Fig. 4). Various challenges arose as the drilling progressed: there were weather delays, problems with hole stability that required frequent reaming, and the drilling assembly became stuck several times. These instances were successfully resolved as they happened. However, the major unsolved problem was a near-complete loss of circulation just below the $9 \frac{5}{8}^{\prime \prime}$ production casing shoe $(2931 \mathrm{~m})$ that could not be cured with lost circulation materials or by 12 successive attempts to seal the loss zone with cement. As cementing was not successful, drilling had to continue without any return of drill cuttings to the surface from deeper than $3200 \mathrm{~m}$, except for drill cuttings that were intermittently sampled between 3000 and $3200 \mathrm{~m}$ depth (Weisenberger et al., 2017).
Consequently, the drill cores are the only deep rock samples recovered from the well.

Figure 4 shows that after the delays attempting to condition the well by repeated cementing, the drilling itself more or less followed the scheduled path, despite several problems on the way down such as stuck drill string, weather delays, etc.

We had considerable difficulties in recovering drill cores in most of the first 10 core runs, and only a total of $27.3 \mathrm{~m}$ of core was retrieved in 13 attempts, or about $63 \%$ recovery of the cored intervals (Table 2). We were using an IDDPdesigned $8 \frac{1}{2}^{\prime \prime}$ coring tool, with $9.7 \mathrm{~m}$ long core barrel (Skinner et al., 2010), which had yielded good core recoveries in $\mathrm{RN}-17 \mathrm{~B}$, an inclined $8 \frac{1}{2}^{\prime \prime}$ hole from $2800 \mathrm{~m}$ depth, and also from three successive core runs below a $9 \frac{5}{8}^{\prime \prime}$ liner in well 


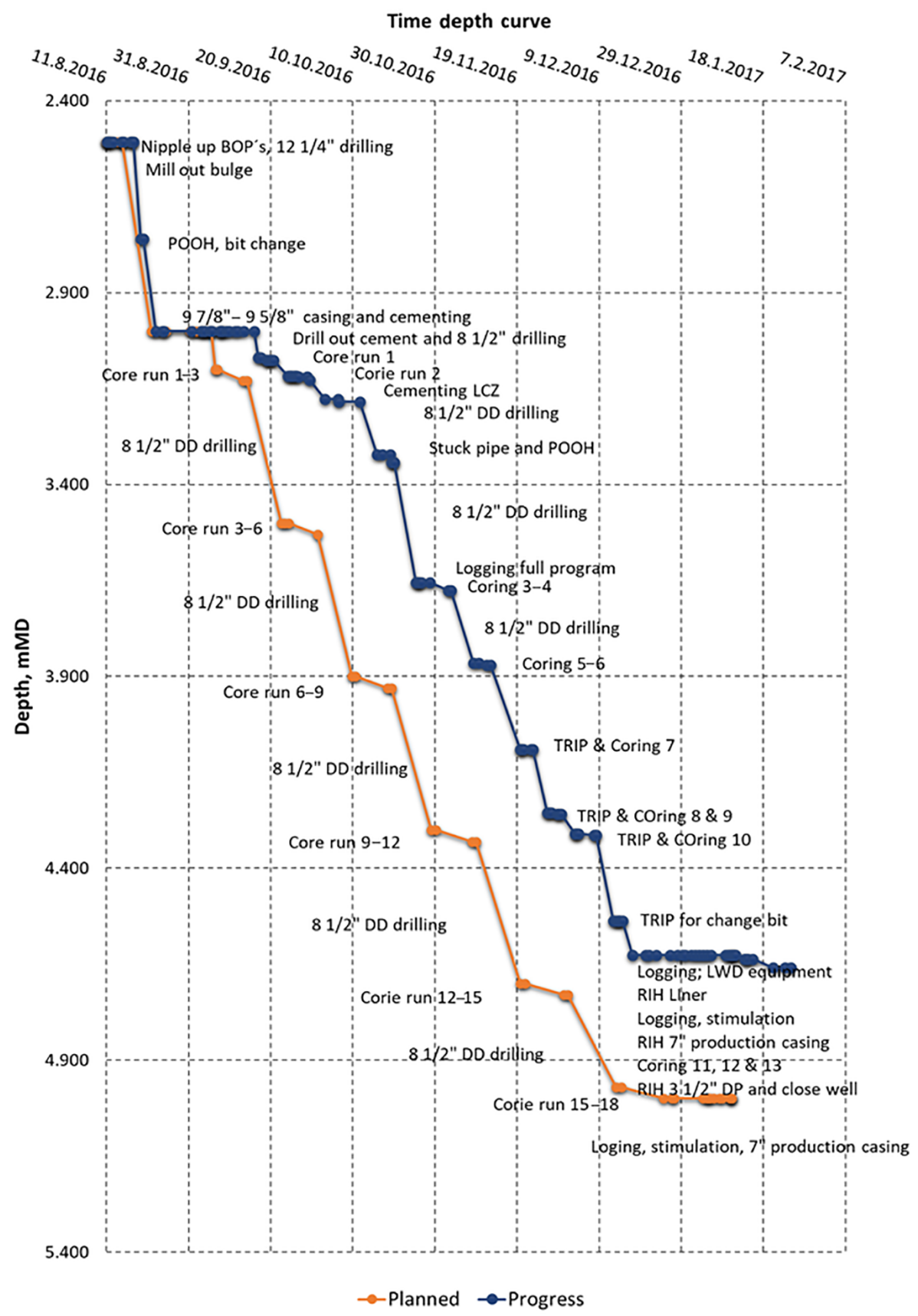

Figure 4. Actual drilling progress of the RN-15/IDDP-2 drill hole (blue) compared to the drilling schedule (orange).

RN-30 at Reykjanes from similar depth to RN-17B (Fowler et al., 2015; Fowler and Zierenberg, 2016). Table 2 gives an overview of the core recovery in 10 core runs with the IDDP $8 \frac{1}{2}^{\prime \prime}$ coring tool and 3 successive core runs with the $6^{\prime \prime}$ Baker Hughes tool at the bottom of IDDP-2, beneath the $7^{\prime \prime}$ liner. Prior to coring with the $6^{\prime \prime}$ tools, an $8 \mathrm{~m}$ deep $6^{\prime \prime}$ pilot hole was drilled with a tri-cone bit from 4626 to $4634 \mathrm{~m}$ to clean out the bottom fill after casing and to condition the well.

A comprehensive analysis of the poor performance of our $8 \frac{1}{2}$ " specially designed coring tool assembly in the IDDP-
2 will appear elsewhere, but there could be several possible reasons for its poor performance. The special feature of our IDDP coring tool is its allowance for much greater water passage (up to $40 \mathrm{~L} \mathrm{~s}^{-1}$ ) for cooling extremely hot rock formation, an order of magnitude higher flow rate than that possible using conventional coring tools. Another characteristic feature of our tool is the relatively soft coring bits, designed for single use only.

Possible reasons for the poor performance of the $8 \frac{1}{2}^{\prime \prime}$ coring assembly are (a) the inclination of the hole, which in- 
creased with increasing depth; (b) possible dog-legs in the hole, which may have damaged the relatively soft drill bits banging against the well wall on running in; (c) rapid cooling leading to thermal fracturing of the formation; and (d) the diameter of the coring tool and reamers, which exceeded the diameter of the heavy drill collars by an inch. Accordingly, the coring bottom-hole-assembly (BHA) was stiffer than the drill collar BHA alone while rotary drilling. Three stabilizers were put in the BHA above the coring tool. In some cases, the $8 \frac{1}{2}$ " tri-cone bit may have been slightly under-sized, adding to the problems. We also often had to ream the hole for considerable lengths before getting to the bottom of the hole; in other cases, fill in the hole may have hindered good coring performance. We attempted to overcome the problems by shortening the core barrel from 10 to $5 \mathrm{~m}$, cutting off all the stabilizers on the BHA, and using only one stabilizer above a heavy drill collar and the BHA. After that modification (in core run 4), we improved the situation considerably and retrieved $3.85 \mathrm{~m}$ of core in a $5 \mathrm{~m}$ long barrel, compared to the 0 to $0.5 \mathrm{~m}$ in preceding runs with the $10 \mathrm{~m}$ barrel. However, the situation did not improve sufficiently to satisfy our need for drill cores. Nevertheless, recovering tens of centimeters of core from depths in the field that were previously not sampled made a huge difference scientifically, compared to having no rock samples at all.

Finally, after casing the well with a 7 " perforated liner, a Baker Hughes $6^{\prime \prime}$ coring tool with a PCD bit (poly crystalline diamond) resulted in very satisfying core recovery at the very bottom of the well. The immediate lesson learned is that in the future we should probably use a slimmer coring assembly in inclined wells, such as drilling $6^{\prime \prime}$ in an $8 \frac{1}{2}^{\prime \prime}$ hole, or $8 \frac{1}{2}$ in a $12 \frac{1}{4}^{\prime \prime}$ hole, etc.

\section{Geophysical and chemical logging during drilling}

We had great expectations for temperature data from the thermocouples installed outside the casing (see above). At first, they seemed to work properly but as time passed, and for unknown reasons, they ceased to transmit data to the surface display, although the casing had not heated above $100^{\circ} \mathrm{C}$. The fiber optic cable may still be operational, but will not be used until the well heats up. A gas spectrophotometer and sampling device on the flowline was provided and set up by the ICDP-OSG at GFZ, and conductivity and $\mathrm{pH}$ sensors were set up by ISOR and HS Orka. These devices were kept operational throughout the drilling of the well. However, they provided no useful data during drilling because, as explained above, there was total loss of circulation throughout almost the entire drilling operation.
Conventional downhole geophysical logs were attained after drilling to $3000 \mathrm{~m}$ depth, and also when the well was $3648 \mathrm{~m}$ deep. Normal resistivity, neutron and natural gamma, and sonic logs were obtained from a casing depth to $3440 \mathrm{~m}$. A televiewer log was attempted but had poor quality (Weisenberger et al., 2016, 2017). Close to the end of drilling, when the well was $4626 \mathrm{~m}$ deep, special LWD (logging while drilling) tools were hired from Weatherford International and used for the first time in Iceland. The logging suite consisted of natural gamma, temperature, pressure, and multi-frequency resistivity from casing to $4615 \mathrm{~m}$. Microresistivity imaging was obtained to $4490 \mathrm{~m}$ (good quality) and acoustic velocity to $3045 \mathrm{~m}$. The results will be described elsewhere. Following this, and after only 6 days of heating (3 January 2017), the temperature measured at the bottom of the well was $\sim 426^{\circ} \mathrm{C}$ with a fluid pressure of $34 \mathrm{MPa}$, and good indications of permeability at depth (at $\sim 3400$, $\sim 4375, \sim 4550 \mathrm{~m}$ ) based on inflections in the downhole temperature profile (Fig. 5). The fluid at the bottom of the well at that time was inferred to be a mixture of injected water and formation fluids. Both the temperature and the pressure indicate that the bottom fluid was at supercritical conditions during the logging operation. Accordingly, one of the main objectives of the IDDP drilling project was achieved, i.e., to drill into supercritical fluid conditions.

In addition to the major loss zone at $3360-3380 \mathrm{~m}$, there are less permeable loss zones further downhole. There are several feed points below the $2931 \mathrm{~m}$ casing shoe all masked by a large feed zone near $3400 \mathrm{~m}$ and 6 smaller feed points at $3820,3990,4100,4200,4375$, and $4550 \mathrm{~m}$, and possibly also at the very bottom of the well below the depth of the temperature $\log$ (Fig. 5). It is clear from the deepest drill cores that we had some open space in fractures containing pristine supercritical fluid down to the bottom of the well $4659 \mathrm{~m}$.

The 7 " perforated hanging liner was inserted to the bottom after the pressure-temperature (PT) logging run of 3 January 2017. Subsequently, a $7^{\prime \prime}$ sacrificial casing was lowered from the surface down to $1300 \mathrm{~m}$ and cemented up to the surface. Casing shoes were then drilled out and the well was deepened using $6^{\prime \prime}$ bits, ending with three successive coring runs down to the $4659 \mathrm{~m}$ final depth. After the deepest coring run, a $3 \frac{1^{\prime \prime}}{2}$ drill string was lowered to the bottom of the hole. The aim was to enhance the permeability deep in the hole by pumping in cold water for several months through the $3 \frac{1}{2}{ }^{\prime \prime}$ drill string. There are already some positive indications of enhancement of injectivity. Tests made after the last coring runs showed that cold water injection increased the injectivity index from 1.7 to $3.1 \mathrm{~L} \mathrm{~s}^{-1} \mathrm{bar}^{-1}$. We expect that continued deep stimulation with cold water is likely to further improve the fracture permeability at depth. While this "soft stimulation" is going on, a surface test bed, with two parallel flowlines, will be designed and constructed for long-term flow testing. Only after these fluid handling and flow tests are concluded will we be able to determine the nature of the formation fluids, their enthalpy and flow characteristics, and hence estimate their engi- 


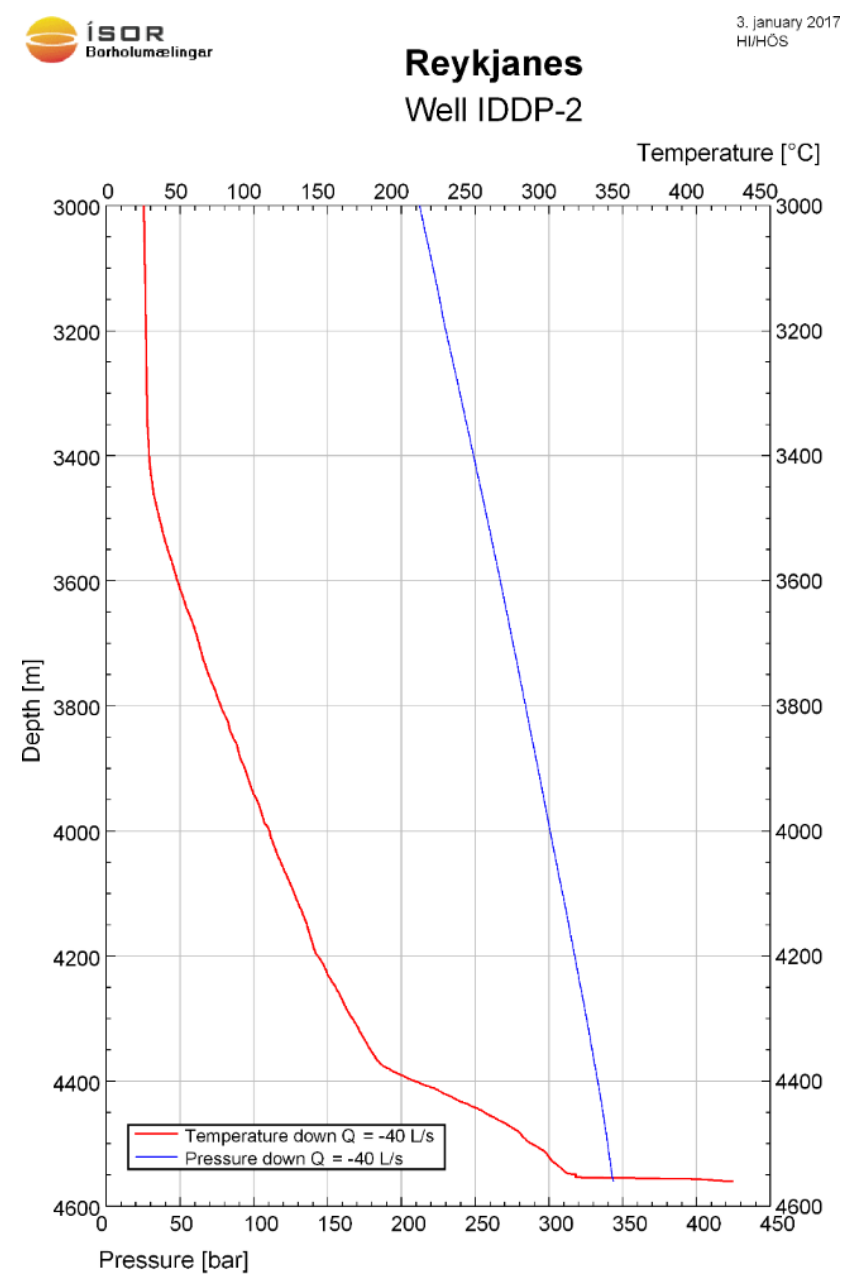

Figure 5. Temperature and pressure $\log$ to $4560 \mathrm{~m}$ depth in IDDP-2 after only 6 days of heating. As can be seen from the temperature profile, the well is far from thermal equilibrium because of cold water injection. When thermal recovery is complete, it is likely that temperatures will exceed the estimated $426^{\circ} \mathrm{C}$ measured at the bottom of the hole. The PT logging was done with a K-10 logging tool, which was calibrated to only $380^{\circ} \mathrm{C}$ (Weisenberger et al., 2017).

neering and economic potential. The total loss of circulation below $3 \mathrm{~km}$ depth was unexpected but the existence of large permeability, a kilometer deeper than the current production zones at Reykjanes, may have implications for the future development of the geothermal resource that are independent of supercritical production.

\section{Lithology and alteration}

A detailed description of the lithologic section drilled in the IDDP-2 well is hampered by total circulation loss below $\sim 3200 \mathrm{~m}$ and is based on preliminary observations of recovered drill cores (Table 2). Despite these limitations, a relatively coherent picture of downhole lithology and hydrothermal alteration is apparent, and is generally consistent with observations from the deepest holes drilled into in situ oceanic crust at fast-spreading ridges by the Deep Sea Drilling Project (DSDP)/Ocean Drilling Program (ODP)/Integrated Ocean Drilling Program (IODP), wells 504B (Costa Rica Rift, Galapagos Spreading Center) and well 1256B (Guatemala Basin, eastern tropical Pacific) (Alt et al., 1986, 2010; Anderson et al., 1982).

The upper $2500 \mathrm{~m}$ of the IDDP-2 well was drilled in 2004 as the former production well $\mathrm{RN}-15$, which is described by Jónsson et al. (2010). Cuttings recovered during deepening of the well down to the lost circulation zone at $3200 \mathrm{~m}$ are described by Weisenberger et al. (2017). Here we focus on the drill core recovered at spot intervals in the depth interval between 3648 and $4659 \mathrm{~m}$.

\section{Primary lithology}

Analysis of drill cuttings indicates that the uppermost section of RN-15 down to about $1400 \mathrm{~m}$ is dominantly volcanic rock with interbedded zones of basalt flows, basalt breccia, pillow lavas, and hyaloclastite. Basaltic intrusions increase in frequency downhole below $\sim 1400 \mathrm{~m}$, and mixed intrusive and extrusive rocks continue to at least $3200 \mathrm{~m}$. Variably rounded cobbles and fragments of volcanic rock derived from below the casing depth $2940 \mathrm{~m}$ were recovered as rubble on top of several of the cores. It is likely that many of these were derived from an enlarged eroded section of the drill hole around $\sim 3360 \mathrm{~m}$ depth, coincident with a major circulation loss zone in the well. The zone from $\sim 1400$ to $\sim 3500 \mathrm{~m}$ depth is, therefore, interpreted as the transition zone between overlying volcanic rocks and an underlying sheeted dike complex (Fig. 6). The preliminary interpretation of the lithological structure and major alteration mineral zones identified in IDDP-2 compared to DSDP/ODP/IODP holes 504B (Costa Rica Rift, Galapagos Spreading Center) and $1256 \mathrm{D}$ (Guatemala Basin, eastern tropical Pacific) is presented on Fig. 6.

The shallowest cored interval extends from 3648.00 to $3648.52 \mathrm{~m}$ and recovered sections of three dikes separated by two chilled margins that indicate that at least the upper two dikes are half-dikes intruded by the underlying dike. Lithologic interpretation based on sparse core recovery is subject to large uncertainty, however, all of the underlying drill core can be reasonably interpreted to have come from a sheeted dike complex with no definitive evidence that they represent either coarse-grained basalt from flow interiors or thick intrusive sills or fine-grained gabbro bodies. Interpretation of the downhole geophysical logs may provide further evidence of the nature of the lithologies in-between the cored intervals as well as orientations of the contacts between intrusive units. Cores 5 and 6 recovered a relatively coarse-grained diabase with no apparent systematic grain-size variation extending from 3865.50 to $3869.95 \mathrm{~m}$. Cores $11-13$ provide the most continuous recovery, with four half-dikes separated by three 


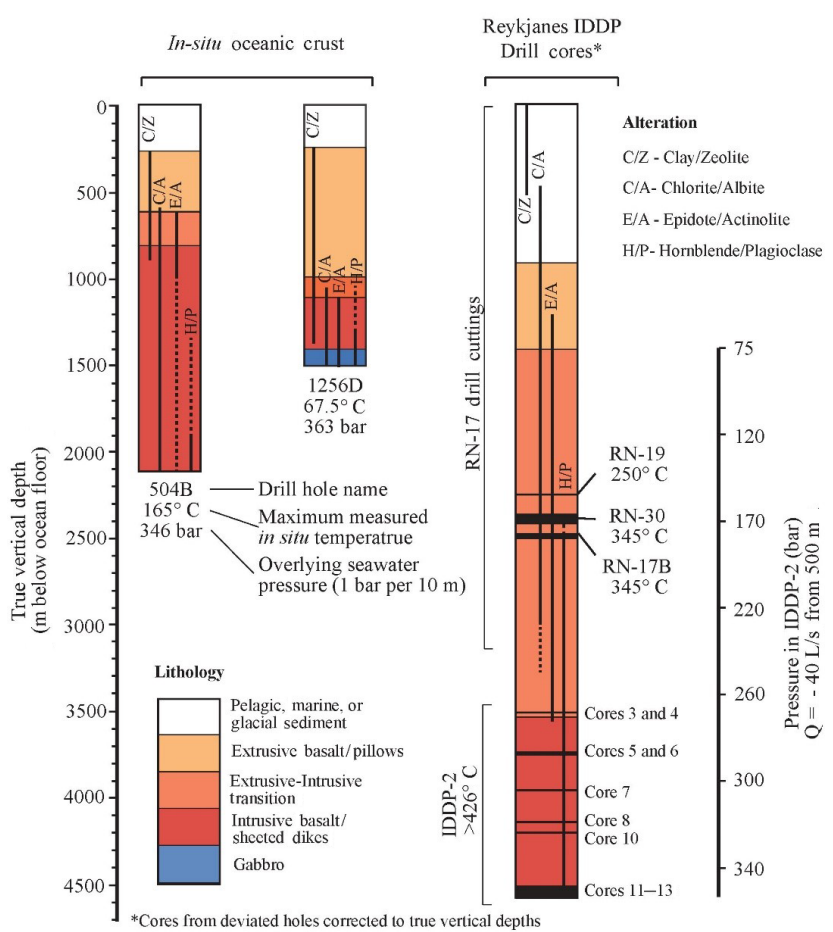

Figure 6. Simplified alteration and lithology logs of RN-15/IDDP2 compared to the two deepest DSDP/ODP/IODP drill holes completed in situ oceanic crust (Hole 504B and Hole 1256D). Maximum temperature and pressure conditions are indicated. The structure of the Reykjanes geothermal system differs from 504B and $1256 \mathrm{D}$ in that the transition zone between the upper pillow basalt section and lower sheeted dike section is greatly expanded at Reykjanes. On a broad scale, alteration mineral sequences in the active Reykjanes system vary predictably as a function of depth in the crust and temperature. Overprinting alteration mineral sequences in rocks from Holes 504B and 1256D reflect time-integrated changes in hydrothermal conditions as rocks tectonically migrated away from active hydrothermal conditions at the spreading center. Data for DSDP/ODP/IODP holes from Alt et al. (2010); Anderson et al. (1982); and Marks et al. (2010). Data for shallower portions of Reykjanes from Marks et al. (2010); Fowler et al. (2015); and Fowler and Zierenberg (2016).

chilled margins recovered between 4634.20 and 4656.00. The thickest half-dike extends $14.4 \mathrm{~m}$ downhole implying a minimum thickness greater than $9 \mathrm{~m}$, given the inclination of the drill hole of approximately $40^{\circ}$ and assuming the dike is vertical.

All the recovered dikes show similar primary mineralogy with subequal concentrations of plagioclase and clinopyroxene accompanied by 3-6\% titanomagnetite. The only apparent exceptions are the uppermost half-dike in core 11, which appears from hand specimen descriptions to contain $\sim 2 \%$ euhedral green partially altered olivine crystals, and the halfdike in the lowermost $1.5 \mathrm{~m}$ of core 12 , which is described as containing approximately $15 \%$ dark blocky clinopyroxene $(2-3 \mathrm{~mm})$ and $20 \%$ finer-grained beer-bottle brown or- thopyroxene $(\sim 2 \mathrm{~mm})$. Given that all recovered cores are overprinted by hydrothermal alteration, estimates of original mineral percentages are uncertain. Plagioclase tends to be slightly coarser-grained (3-4 mm), elongated, and more euhedral compared to clinopyroxenes, which tends to occur interstitial to the plagioclase matrix.

Irregular patches and vein-like segregations of more differentiated felsic melt are a minor component of some of the dikes and become increasingly common downcore. The first noted occurrence of these segregations is in core 5, which shows a few irregular discontinuous lighter colored veins characterized by an increased abundance of late-stage igneous plagioclase, some of which appears cloudy due to symplectic intergrowth with very fine-grained quartz. Clinopyroxene is less abundant in these veins, and some formed as thin $(\leq 1 \mathrm{~mm})$ elongated prisms up to $5 \mathrm{~mm}$ long. All of the pyroxene in this core interval has been replaced by hydrothermal amphibole. Core 10 contains a $3 \mathrm{~cm}$ thick plagioclase-quartz-clinopyroxene-titanomagnetite segregation vein, where quartz occurs as coarser-grained crystal as well as symplectic intergrowths with plagioclase. Cores 11-13 show an increased abundance of felsic segregation patches, irregular veinlets and veins up to $5 \mathrm{~cm}$ thick (Fig. 7), and many of these include green to brown biotite as a primary igneous mineral, which in some veins is more abundant than clinopyroxene. Preliminary examination of thin sections reveals that accessory apatite is more abundant in the felsic segregations. Some felsite veins have euhedral zircon crystals up to $2 \mathrm{~mm}$ in length. Rock of rhyolitic compositions, although common in other Icelandic volcanic centers such as Krafla (e.g., Jónasson, 2007), have not been observed previously at Reykjanes.

\section{Alteration and hydrothermal veining}

The assemblage of alteration minerals observed in cuttings from RN-15 (Jónsson et al., 2010) and the upper section of IDDP-2 above the lost circulation zone (Weisenberger et al., 2017) is consistent with the downhole prograde alteration assemblages described by Tómasson and Kristmannsdóttir (1972). Cuttings from the production reservoir of the Reykjanes field show epidote-actinolite facies alteration characterized by replacement, open-space filling veins, and vug-filling alteration minerals dominated by chlorite, epidote, actinolite, albite, and quartz.

The upper-most core samples from IDDP-2 (core 3, $3648 \mathrm{~m}$ ) are pervasively altered and intensively veined by epidote, amphibole, plagioclase (with or without quartz) with chlorite-rich vein selvages. Igneous clinopyroxene is completely replaced by amphibole and chlorite. Igneous plagioclase shows patchy alteration to albite, epidote, and chlorite. Titanomagnetite is partially replaced by magnetite and titanite. Minor phases include pyrite, pyrrhotite, and intermediate solid solution $\mathrm{Cu}-\mathrm{Fe}$ sulfide. Hydrothermal clinopyrox- 


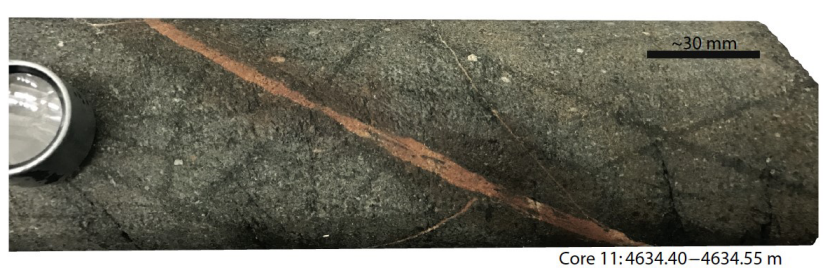

Figure 7. A piece of core from the RN-15/IDDP-2 well from 4634.40 to $4634.55 \mathrm{~m}$ depth, showing felsite veins and conjugate sets of older fractures/veins. The red color of the felsite relates to hematic stain formed from a mixture of supercritical vein fluid with cold oxidizing drilling fluid (see text for further discussion).

ene is present in veins and groundmass replacement of the fine-grained to formerly glassy quenched dike margins. The epidote veins are somewhat anastomosing and dip in multiple directions. Some veins show clear cross-cutting relationships while others merge into composite veins. In contrast to alterations observed in overlying cuttings, textures indicative of open-space fracture fillings are absent and quartz is much less abundant, occurring as a minor phase in the veins. Actinolite is the dominant amphibole, but is locally replaced by hornblende. Plagioclase in the veins is calcic, ranging to near end-member anorthite. The presence of hornblende and calcic plagioclase is an indication that rocks have reached PT conditions of the amphibole alteration facies, but the rocks have not reached equilibrium. Overprinting of epidote-actinolite facies by amphibole facies alteration is an indication of prograde expansion of the hydrothermal system and/or subsidence of these rocks to higher PT conditions.

The alteration observed in the deeper sections of core, starting with core 5 at $3865 \mathrm{~m}$, is consistent with amphibolite facies alteration. Epidote and chlorite are not present and quartz, if present, is a minor phase. In most of the deeper cores, igneous clinopyroxene is pervasively to completely altered to amphibole, but igneous plagioclase generally appears to be unaltered. Actinolite persists at depth, but hornblende becomes increasingly abundant downhole. Albitization of plagioclase is minor to absent. The dominant vein minerals are amphibole and calcic plagioclase, which can occur separately or together. Plagioclase-rich veins may contain minor amounts of quartz, but quartz is absent from most hydrothermal veins and is most common in and adjacent to the felsite segregation patches and veins/dikelets. Although most of the cores show pervasive alteration, cross-cutting veins are volumetrically a very minor component of the rock. The veins tend to be thin (1-4 mm), irregular, and discontinuous and lack evidence of filling of open space, consistent with formation in the brittle/ductile transition zone. Trace amounts of hydrothermal biotite and clinopyroxene are noted as shallow as core 8 (4254 $\mathrm{m})$.

The most continuous core recovery was achieved at the bottom of the hole from 4634 to $4659 \mathrm{~m}$. Most of the dikes in this section show pervasive alteration of igneous clinopyrox- ene to hornblende, but relict igneous pyroxene is preserved in some dikes. Hydrothermal biotite is less abundant than amphibole, but is intergrown with hornblende in the deeper rocks. Igneous plagioclase retains its morphology and growth zoning patterns but is locally cloudy and dusted with iron oxide and vapor-rich inclusions. Hydrothermal veining is very minor for most of this interval but there are local zones of millimeter scale, cross-cutting hornblende and hornblende plus plagioclase veins. Thin (1-2 mm wide) discontinuous, anastomosing veinlets of plagioclase and quartz that may be accompanied by hornblende and/or biotite branch off the felsite segregation veins/dikeletts, and the distinction between igneous and hydrothermal deposition/alteration is obscure at present. One mineralized open fracture was recovered along the margin of a $3 \mathrm{~cm}$ wide felsite vein $(4637.19 \mathrm{~m})$. The fracture was covered by coarse-grained euhedral hydrothermal biotite (Fig. 8a) that was overgrown by later, fine-grained euhedral quartz (Fig. 8b), including doubly terminated prismatic crystals. The fracture and the adjacent core surfaces were stained and locally coated by hematite that, based on textural relations, clearly formed during the drilling process by oxidation of ferrous iron bearing formation fluid interacting at high temperature with oxygenated surface water pumped downhole for cooling. Similar hematite staining is increasingly abundant in patchy intervals downhole, becoming very common in core 13 . The hematite staining is restricted to surfaces cut by the core bit or pre-existing fracture surfaces and is not present on post-coring fractures or the interior of the core that was cut for examination. Sulfides (pyrrhotite and/or intermediate solid solution $\mathrm{Cu}$-Fe sulfide) and hydrothermal magnetite are minor, but commonly observed, alteration phases in the deepest cores.

\section{Significance of the IDDP-2}

The IDDP-2 cores include the first samples recovered from active, supercritical geothermal conditions in a seawaterrecharged hydrothermal system analogous to the roots of deep-sea black smoker systems. The lithological section underlying the presently exploited hydrothermal system at Reykjanes is typical of sheeted complexes in oceanic crust and ophiolites. Logging measurements confirm that permeable feed zones are present at temperature and pressure conditions in excess of the critical point of seawater in the deepest section of the well.

The geological environment of the Reykjanes geothermal field is of great interest to the scientific community, situated as it is on the landward extension of the Mid-Atlantic Ridge that forms part of the world-encircling system of divergent plate boundaries, or oceanic spreading centers (Elders and Friðleifsson, 2010). These are regions of frequent volcanic eruption, high heat flow, and submarine hot springs. Base-metal sulfide scales that form in drill holes and production pipes are similar to seafloor massive sulfide deposits 
(a)

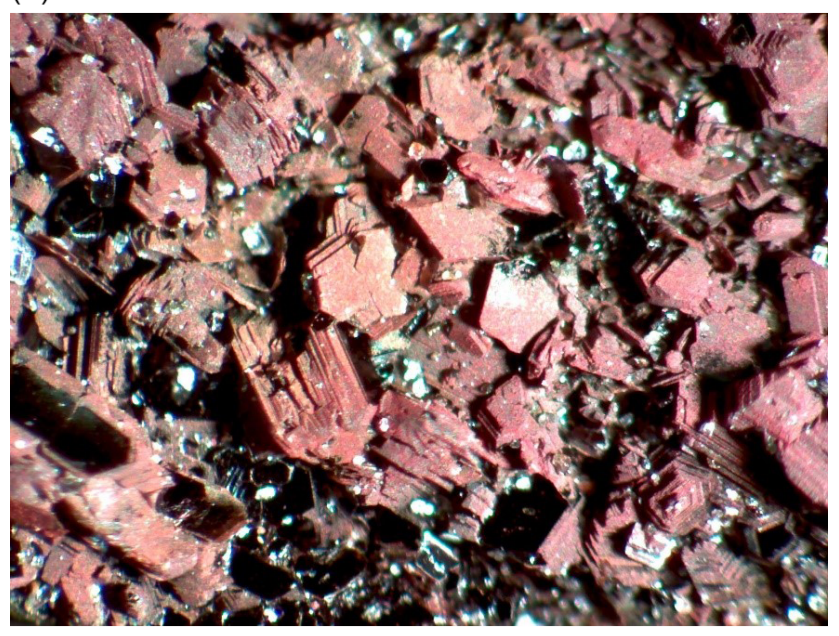

(b)

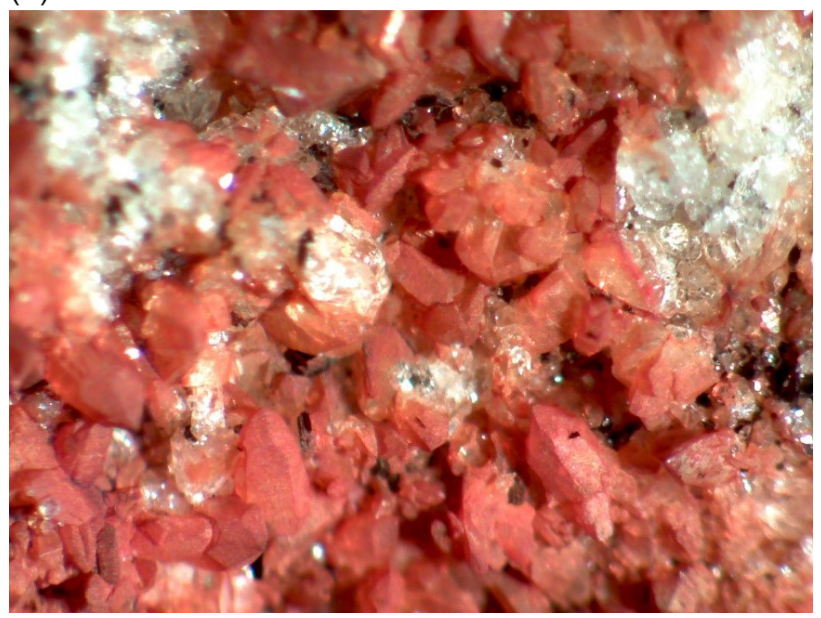

Figure 8. (a) Euhedral hydrothermal biotite books, approximately $1 \mathrm{~mm}$ across, coating fracture surface in RN-15/IDDP-2 (4637.81m depth). Exposed crystals were stained red by hematite during the coring operation. (b) Open-space filling quartz, up to $4 \mathrm{~mm}$ in length, overgrowing hydrothermal biotite (black crystals) in RN15/IDDP-2 (4637.81 m depth). Exposed crystals were stained red by hematite during the coring operation.

(Hardardóttir et al., 2012). The IDDP-2 is a unique opportunity to examine the roots of a black smoker.

In the future, our demonstration that it is possible to drill into a supercritical zone could have a large impact on the economics of high-temperature geothermal resources worldwide, wherever young volcanic rocks occur (Dobson et al., 2017). By extending the available economic reservoir downwards, we can extend the lifetimes of existing producing fields. As higher enthalpy fluids have greater power conversion efficiencies, fewer turbines are required for a given power output. Similarly, as fewer wells are needed for a given output, we can increase the productivity of a geothermal field without increasing its environmental footprint.
More information on the IDDP can be found at www.iddp. is and at www.deepegs.eu.

Data availability. Our underlying research data is partly kept at the following link: https://www.icdp-online.org/projects/world/ europe/iceland/details/ and at an internal IDDP website at icdponline for the IDDP science team only - until published.

Competing interests. The authors declare that they have no conflict of interest.

Acknowledgements. The IDDP-2 was funded by HS Orka, Landsvirkjun, Orkuveita Reykjavíkur, and the National Energy Authority in Iceland, together with Statoil, the Norwegian oil and gas company. The IDDP has also received funding from the EU H2020 (DEEPEGS, grant no. 690771), and science funding from ICDP and NSF. In 2005, funding for IDDP to obtain spot cores at Reykjanes and elsewhere was provided by ICDP and the US NSF (grant no. 05076725), which is greatly appreciated. Successful coring attempts exist from wells RN-17B, RN-19, RN-30, and now from RN-15/IDDP-2, Iceland.

Edited by: Tomoaki Morishita

Reviewed by: Robert O. Fournier and one anonymous referee

\section{References}

Albertsson, A., Bjarnason, J.Ö., Gunnarsson, T., Ballzus, C., and Ingason, K.: Part III: Fluid handling and evaluation, in: Iceland Deep Drilling Project, Feasibility Report, edited by: Friðleifsson, G. Ó., Orkustofnun Report OS-2003-007, 32 pp., available at: http://www.os.is/gogn/Skyrslur/OS-2003/OS-2003-007. pdf, 2003.

Alt, J. C., Honnorex, J., Laverne, C., and Emmermann, R.: Hydrothermal alteration of a $1 \mathrm{~km}$ section through the upper oceanic crust, Deep Sea Drilling Project Hole 504B: Mineralogy, chemistry and evolution of seawater-basalt interactions, J. Geophys. Res., 91, 10309-10335, 1986.

Alt, J. C., Laverne, C., Coggon, R. M., Teagle, D. A. H., Banerjee, N. R., Morgan, S., Smith-Duque, C. E., Harris, M., and Galli, L.: Subsurface structure of a submarine hydrothermal system in oceanic crust formed at the East Pacific Rise, ODP/IODP Site 1256, Geochem. Geophy. Geosy., 11, Q10010, https://doi.org/10.1029/2010GC003144, 2010.

Anderson, R. N., Honnorez, J., Becker, K., Adamson, A. C., Alt, J. C., Emmerman, R., Kempton, P. D., Kinoshita, H., Laverne, C., Mottl, M. J., and Newmarks, R. L.: Hole 504B, the first reference section over $1 \mathrm{~km}$ through Layer 2 of the oceanic crust, Nature, 300, 589-594, 1982.

Anonymous: Penrose Field Conference on Ophiolites, Geotimes, 17, 24-25, 1972.

Bischoff, J. L. and Rosenbauer, R. J.: Liquid-vapor relations in the critical region of the system $\mathrm{NaCl}-\mathrm{H}_{2} \mathrm{O}$ from $380^{\circ} \mathrm{C}$ to $414{ }^{\circ} \mathrm{C}$ : A refined determination of the critical point of seawater, Geochim. Cosmochim. Acta, 52, 2121-2126, 1988. 
Dobson, P., Asanuma, H., Huenges, E., Polletto, F. Reinsch, T., and Sanjuan, B.. Supercritical Geothermal Systems - A Review of Past Studies and Ongoing Research Activities. Proceedings, 41st Workshop on Geothermal Reservoir Engineering Stanford University, Stanford, California, 13-15 February, 1-13, 2017 SGPTR-212, 2017.

Elders, W. A. and Friðleifsson, G. Ó.: Implications of the Iceland Deep Drilling Project for improving understanding of hydrothermal processes at slow spreading mid-ocean ridges. In: Diversity of Hydrothermal Systems on Slow Spreading Ocean Ridges, American Geophysical Union, Geoph. Monog. Ser., 188, 91$112,2010$.

Elders, W. A., Friðleifsson, G.Ó., Zierenberg, R. A., Pope, E. C., Mortensen, A. K., Guðmundsson, Á., Lowenstern, J. B., Marks, N. E., Owens, L., Bird, D. K., Reed, M., Olsen, N. J., and Schiffman, P.: Origin of a rhyolite that intruded a geothermal well while drilling in a basaltic volcano, at Krafla, Iceland, Geology, 39, 231-234, 2011.

Fowler, A. P. G. and Zierenberg, R. A.: Elemental changes and alteration recorded by basaltic drill core samples recovered from insitu temperatures up to $345^{\circ} \mathrm{C}$ in the active, seawater-recharged Reykjanes Geothermal System, Iceland, Geochem. Geophy. Geosy., 17, https://doi.org/10.1002/2016GC006595, 2016.

Fowler, A. P. G., Zierenberg, R. A., Schiffman, P., Marks, N., and Friðleifsson, G. Ó.: Evolution of fluid-rock interaction in the Reykjanes geothermal system, Iceland: Evidence from Iceland Deep Drilling Project core RN-17B, J. Volcanol. Geotherm. Res., 302, 47-63, 2015.

Friðleifsson, G. Ó. and Richter, B.: The geological significance of two IDDP-ICDP spot cores from the Reykjanes geothermal field, Iceland, Proceedings of the World Geothermal Congress 2010, Bali, Indonesia, p. 6, available at: www.iddp.is, 2010.

Friðleifsson, G. Ó., Ármannsson, H., Árnason, K., Bjarnason, I. P., and Gíslason, G.: IDDP Feasibility Report. Iceland Deep Drilling Project, Part I Geosciences - Site Selection. Orkustofnun, Report, OS-2003-007, 103 pp., available at: http://www.os.is/gogn/ Skyrslur/OS-2003/OS-2003-007.pdf, 2003.

Friðleifsson, G. Ó., Elders, W. A., and Bignall, G.: A plan for a $5 \mathrm{~km}$-deep borehole at Reykjanes, Iceland, into the root zone of a black smoker on land, Sci. Dril., 16, 73-79, https://doi.org/10.5194/sd-16-73-2013, 2013.

Friðleifsson, G. Ó., Elders, W. A., and Albertsson A.: The Concept of the Iceland Deep Drillig Project, Geothermics, 49, 2-8, 2014a.
Friðleifsson, G. Ó., Sigurdsson, Ó., Porbjörnsson, D., Karlsdóttir, R., Gíslason, P., Albertsson, A., and Elders, W. A.: Preparation for drilling well IDDP-2 at Reykjanes, Geothermics, 49, 119126, 2014b.

Hardardóttir, H., Hannington, M., Hedenquist, J, Kjarsgaard, I., and Hoal, K.: Cu-rich scales in the Reykjanes geothermal systems, Econ. Geol., 105, 1143-1155, 2012.

Jónasson, K.: Silicic volcanism in Iceland: composition and distribution within the active volcanic zones, J. Geodynam., 43, 101$117,2007$.

Jónsson, S. S., Sigurgeirsson, M. A., Sigurðsson, Ó., and Ingólfsson, H.: Reykjanes -Hola RN-15, 3. phase: Drilling of the production part from $804 \mathrm{~m}$ to $2507 \mathrm{~m}$ (in icelandic), ÍSOR Report 2010/050,69 pp., 2010.

Marks, N., Schiffman, P., Zierenberg, R., Franzson, H., and Friðleifsson, G.Ó.: Hydrothermal alteration in the Reykjanes geothermal system: Insights from Iceland deep drilling program well RN-17, J. Volcanol. Geoth. Res., 189, 172-190, 2010.

Skinner, A., Bowers, P., Pórhallsson, S., Friðleifsson, G.Ó., and Guðmundsson, H.: Extreme coring, designing and operating a core barrel for the Iceland Deep Drilling Project, GeoDrilling Int., 2010, 18-22, 2010.

Tómasson, J. and Kristmannsdóttir, H.: High temperature alteration minerals and thermal brines, Reykjanes, Iceland, Contributions to Mineralogy and Petrology, 36, 123-134, 1972.

Weir, N. R. W., White, R. S., Bandsdóttir, B., Einarsson, P., Shimamura, H., Shiobara, H., and the RISE Fieldwork Team: Crustal structure of the northern Reykjanes Ridge and Reykjanes Peninsula, southwest Iceland, J. Geophys. Res., 106, 6347-6368, 2001.

Weisenberger, T. B., Kästner, F., Níelsson, S., Harðarson, B. S., Kristinsson, B., Ingólfsson, H., Stefánsson, H.Ö., Jónasson, H., and Vilhjálmsson S.: Well Report - RN-15/IDDP-2, Drilling of Well RN-15/IDDP-2 in Reykjanes - Continuation of Phase 3 from $2509 \mathrm{~m}$ down to $3000 \mathrm{~m}$, Iceland GeoSurvey, report, ÍSOR2016/053, 2016.

Weisenberger, T. B., Harðarson, B. S., Kästner, F., Gunnarsdóttir, S. H., Tulinius, H., Guðmundsdóttir, V., Einarsson, G. M., Pétursson, F., Vilhjálmsson, S., Stefánsson, H. Ö., and Níelsson S.: Well Report - RN-15/IDDP-2, Drilling in Reykjanes - Phase 4 and 5 from 3000 to 4659, ISOR 2017/016, 277 pp., 2017. 